\title{
Optimizing surface soil NPK balance through integrated nutrient management in wheat-soybean cropping system from Rawalakot Pakistan
}

\author{
Abdul Khaliq ${ }^{1}$, Mohsin Zafar ${ }^{1 *}$, Muhammad Kaleem Abbasi ${ }^{1}$, Majid \\ Mahmood Tahir ${ }^{1}$ and Sair Sarwar ${ }^{2}$ \\ 1. Department of Soil and Environmental Sciences, University of the Poonch Rawalakot, Azad Jammu and \\ Kashmir-Pakistan \\ 2. Land Resources Research Institute (LRRI) National Agricultural Research Centre (NARC) Islamabad-Pakistan \\ *Corresponding author's email: mohsinses@gmail.com
}

\section{Citation}

Abdul Khaliq1, Mohsin Zafar1, Muhammad Kaleem Abbasi1, Majid Mahmood Tahir1 and Sair Sarwar. Optimizing surface soil NPK balance through integrated nutrient management in wheat-soybean cropping system from Rawalakot Pakistan. Pure and Applied Biology. Vol. 8, Issue 4, pp2373-2388.

http://dx.doi.org/10.19045/bspab.2019.80183

Received: 19/03/2019 Revised: 20/07/2019 Accepted: 24/08/2019

Online First: 07/09/2019

\section{Abstract}

The efficient use of organic-inorganic amendments and changing cropping pattern are important management strategies to improve crop productivity as well as restore the nutrient buildup of degraded soils. A three-year (2008-09 to 2010-11) soybean-wheat rotation field experiment was conducted at Rawalakot, Azad Jammu and Kashmir. Treatments included PM $\mathrm{PM}_{100}, \mathrm{WSR}_{100}, \mathrm{PM}_{50}+\mathrm{WSR}_{50}, \mathrm{UN}_{100}$, $\mathrm{UN}_{50}+\mathrm{PM}_{50}, \mathrm{UN}_{50}+\mathrm{WSR}_{50}, \mathrm{UN}_{50}+\mathrm{PM}_{25}+\mathrm{WSR}_{25}$ and a control (unfertilized). Applications of amendments were made on N-equivalent basis at the rate of $100 \mathrm{~kg} \mathrm{~N} \mathrm{ha}^{-1}$. Data on surface NPK balance showed a net depletion of $41.2 \mathrm{~kg} \mathrm{~N} \mathrm{ha}^{-1} \mathrm{year}^{-1}$ and gain of 95.8 and $16.5 \mathrm{~kg} \mathrm{ha}^{-1} \mathrm{year}^{-1}$ of phosphorus (P) and potassium $(\mathrm{K})$ for the control soil during three years. Soil amended with either organic amendments (PM and WSR) and $\mathrm{UN}$ alone or combination of both organic amendments $+\mathrm{UN}$ yielded positive surface $\mathrm{N}$ and $\mathrm{P}$ balance that varied between 40.7-86.8 and 84.5-213.7 $\mathrm{kg} \mathrm{ha}^{-1} \mathrm{year}^{-1}$, respectively under different amendments. The $\mathrm{UN}_{100}$ and $\mathrm{UN}_{50}+\mathrm{PM}_{50}$ treatments showed a K deficit of 12 and17.1 kg ha-1 year ${ }^{-1}$, respectively while $\mathrm{UN}_{50}+\mathrm{WSR}_{50}$ and $\mathrm{UN}_{50}+\mathrm{PM}_{25}+\mathrm{WSR}_{25}$ treatments marginally increased soil $\mathrm{K}$ content between $1.3-5.2 \mathrm{~kg}$ ha $^{-1}$ year $^{-1}$ compared to $16.5 \mathrm{~kg} \mathrm{ha}^{-1}$ year $^{-1}$ in the control treatment. Treatments receiving repeated applications of poultry manure alone or with $\mathrm{UN}$ has the potential to improve the surface $\mathrm{N}$ and $\mathrm{P}$ balances. Therefore, it is recommended to increase annual addition of $\mathrm{K}$ fertilizer (beyond $50 \mathrm{~kg} \mathrm{~K}_{2} \mathrm{O}$ ha $^{-1}$ year ${ }^{-1}$ ) with organicinorganic amendments to maintain $\mathrm{K}$ balance and sustain long-term soybean-wheat productivity of degraded soils of Himalayan Hindukush of Azad Jammu and Kashmir.

Keywords: Integrated fertilization; Nutrient balance; Surface soil; Wheat straw residue

\section{Introduction}

Plant nutrient budgeting is a system of gross evaluations of sustainability of agro- ecosystems that monitors nutrient flows to and from fields (nutrient inputs and outputs), determines yield levels and evaluates soil 
health and quality. Nutrient budget analyses are also of particular importance in addressing the environmental problems associated with nutrient accumulations/ depositions from excessive applications of organic manures and can serve as useful devices to both general public and policymakers [1]. Calculations for nutrient budgets on a variety of scales (from plot and catchment to continental scales) provide information regarding the present nutrient status and dynamics of soil fertility. The introduction of high yield potential cultivars of crops, increased cropping intensity, greater erosion and lack of nutrient inputs from either organic or manufactured nutrient sources commonly contributed to the nutrients mining, fertility depletion and negative nutrient balances in soil [2]. In addition, nutrient uptake pattern of different crops provides a fair estimate of the crop demands for the specific nutrients and the extent to which mining of the soil nutrient might be critical for optimizing crop productivity. Numerous long-term field studies [3] conducted in Asian region on yield and fertility evaluation had shown that elevated nutrient deficiencies, low soil organic matter, nominal use of animal manures and other organic nutrient sources and inappropriate/ imbalanced nutrient management are mainly attributed to the fertility depletion with the consequent reduction in yields.

Supplementing the nutrients particularly $\mathrm{N}$ from manufactured fertilizers is not sufficient to restore long term soil fertility and to maintain nutrient balance because of significant unwanted losses of applied nutrients. Mismanagement of $\mathrm{N}$ fertilizer causes economic losses, environmental degradation and gaseous emissions that adversely affect the sustainability of crop productivity. [4] estimated that more than $50 \%$ of total applied $\mathrm{N}$ fertilizer from agricultural systems is volatilized into the atmosphere or washed into water reservoirs via leaching, runoff and erosion causing environmental pollution and annual economic loss of about US\$ 17 billion. In addition, there are some other reports that continuous use of excessive mineral $\mathrm{N}$ fertilizers gradually declines soil organic matter level, increases soil acidity, causes micronutrient deficiencies and accelerates land and environmental degradation [5]. Organic manures particularly poultry manure (PM) and crop residues are the other important nutrient sources that add substantial amounts of nutrients through mineralization into the mineral pool of soil and play an important role in sustaining crop productivity [6]. In conventional farming systems, the repeated application of PM is thought to be more effective and superior than chemical fertilizers for improving the yield of some agricultural crops because of balanced nutrients supply and its longer persistence in soil [7]. Similarly, [8] documented that the application of organic manures as soil amendment increases the availability of nutrients because of nutrients release in soil from native pool as well as their long lasting residual effects. In addition, numerous previous studies [9] had revealed that besides containing 2.5 to $3.0 \%$ total $\mathrm{N}$, PM has the potential to supply considerable amounts of $\mathrm{P}, \mathrm{K}$ and some of the micronutrients and its long-term utilization sustains soil fertility and productivity.

Both the manures and chemical fertilizers alone cannot sustain long-term productivity of the traditionally grown maize and wheat crops in Azad Jammu and Kashmir, therefore, ecological acceptable and practically feasible crop-soil nutrient management approaches like integrated nutrient management (INM) and introduction of legume-based cropping system such as soybean-wheat rotation need urgent attentions for improving nutrients availability and sustaining long-term crop productivity. The judicious combination of organic- 
inorganic nutrient sources maintains soil health, crop productivity, augments efficiency of added nutrients (synergistic effect), improves soil physical conditions and results in better utilization of both water and nutrients from the soil [10]. The integrated management of nutrients results in sustainable crop production, build-up of total soil carbon pool, improves the level of major soil nutrients especially nitrogen and phosphorus and reduces the risk of environmental pollution [11].

The legume-based rotation of cereals is also an important component of profitable cropping systems because legumes fix substantial amounts of atmospheric $\mathrm{N}_{2}$ and represent a renewable source of $\mathrm{N}$ for agriculture. In addition, soil incorporation of legume residues, roots and senescenced nodules adds $25 \%$ of their $\mathrm{N}$ through mineralization for subsequent cereal crop and improves organic matter level of the soil [12]. The objective of this study was to evaluate the short-term changes in nutrient balances of soil supplemented with organic-inorganic amendments in wheat- soybean cropping system.

\section{Materials and methods \\ Description of experimental site}

The study site was located in an experimental farm of University of the Poonch Rawalakot, Azad Jammu and Kashmir, in the north-east of Pakistan under the foothills of great Himalayas. The area lies between the altitude of 1800-2000 $\mathrm{m}$ above sea level and latitude $33-36^{0}$. The topography is mainly hilly and mountainous with valleys and stretches of plains. The area is characterized by a temperate sub-humid climate with annual average rainfall ranging from about 500-2000 mm, most of which is irregular and falls with intense storms during monsoon and winter. Mean annual temperature is about 28 ${ }^{\circ} \mathrm{C}$ (maximum) in summer while winter is fairly cold with temperature ranging even below freezing point. The monthly precipitation and temperature of the experimental area during the investigation years (2008-09, 2009-10, and 2010-11) are presented in (Table 1). A series of field experiments was carried-out during three consecutive years on loam (Thermic Lithic Eutrudepts) soil, developed from the colluvial parent materials.

\section{Experimental details}

Before the onset of the experiment and for proper field bed preparation, the field was plowed 2-3 times to a depth of about twenty $\mathrm{cm}$ and left as such for the next two weeks. The treatments were comprised of all combinations of three sources of $\mathrm{Na}$ a) organic $\mathrm{N}$ sources i) animal origin i.e. poultry manure (PM) ii) plant origin i.e. wheat straw residues (WSR) b) mineral $\mathrm{N}$ as urea (UN) and a control (no N). These amendments were applied alone or integrated with different combinations. Altogether, a total of eight treatments were used. Nitrogen from different treatments was applied at the rate of $100 \mathrm{~kg} \mathrm{~N} \mathrm{ha}^{-1}$ generally recommended as optimum $\mathrm{N}$ rate for wheat and soybean under environmental conditions of the region. The $\mathrm{N}$ rates from $\mathrm{PM}$ and WSR were calculated on the basis of total $\mathrm{N}$ content in both the organic sources i.e. $2.57 \%$, and $0.91 \%$, respectively (Table 2). 
Table 1. Meteorological data i.e. total rainfall and minimum and maximum temperature of the experimental site Rawalakot for three years $(2009,2010$ and 2011)

\begin{tabular}{|c|c|c|c|c|c|c|c|c|c|}
\hline \multirow{2}{*}{$\begin{array}{c}\text { Months of } \\
\text { year }\end{array}$} & $\begin{array}{c}\text { Total } \\
\text { rainfall } \\
(\mathbf{m m})\end{array}$ & $\begin{array}{c}\text { Min. } \\
\text { Temp. } \\
\left({ }^{\circ} \mathrm{C}\right)\end{array}$ & $\begin{array}{c}|c| \\
\text { Year 2009 } \\
\text { Temp. } \\
\left({ }^{\circ} \mathrm{C}\right)\end{array}$ & $\begin{array}{c}\text { Total } \\
\text { rainfall } \\
(\mathbf{m m})\end{array}$ & $\begin{array}{c}\text { Min. } \\
\text { Temp. } \\
\left({ }^{\circ} \mathrm{C}\right)\end{array}$ & $\begin{array}{c}\text { Max. } \\
\text { Temp. } \\
\left({ }^{\circ} \mathrm{C}\right)\end{array}$ & $\begin{array}{c}\text { Total } \\
\text { rainfall } \\
(\mathbf{m m})\end{array}$ & $\begin{array}{c}\text { Min. } \\
\text { Temp. } \\
\left({ }^{\circ} \mathrm{C}\right)\end{array}$ & $\begin{array}{c}\text { Max. } \\
\text { Temp. } \\
\left({ }^{\circ} \mathrm{C}\right)\end{array}$ \\
\hline January & 103.2 & -0.8 & 12.8 & 38.5 & -1.3 & 15.6 & 20.0 & -3.5 & 12.1 \\
\hline February & 148 & 0 & 12.9 & 295.2 & 0.1 & 11.9 & 328 & -0.2 & 11.1 \\
\hline March & 145 & 3.2 & 17.9 & 83.2 & 5.2 & 21.7 & 164.6 & 3.2 & 18.2 \\
\hline April & 200 & 5.9 & 21.8 & 44.9 & 7.7 & 25.0 & 231.1 & 6.0 & 20.0 \\
\hline May & 41 & 9.9 & 27.5 & 135 & 10.2 & 26.0 & 27.5 & 12.1 & 28.0 \\
\hline June & 160 & 11.4 & 28.2 & 59.1 & 12 & 27.3 & 112.6 & 15 & 28.3 \\
\hline July & 217.6 & 15.3 & 28.6 & 256.1 & 16.1 & 26.5 & 217.3 & 16.4 & 25.8 \\
\hline August & 167 & 16.4 & 27.4 & 169.9 & 17.2 & 25.4 & 258.7 & 17.2 & 25.6 \\
\hline September & 81.5 & 11.7 & 27.2 & 25.9 & 13.9 & 26.2 & 167.3 & 14.4 & 25.7 \\
\hline October & 29 & 5.3 & 23.3 & 78.9 & 7.0 & 23.5 & 25.7 & 7.1 & 23.2 \\
\hline November & 39 & 1.0 & 18.7 & 2.0 & 2.6 & 20.9 & 11.3 & 2.5 & 20.4 \\
\hline December & 39.3 & -0.8 & 14.9 & 28.1 & -1.9 & 16.1 & 12.3 & -1.8 & 15.5 \\
\hline
\end{tabular}

Source: The Directorate, Regional Meteorological centre, 46-Jail Road, Lahore, Pakistan

Table 2.The detail of treatment combinations is described in the below given

\begin{tabular}{|c|c|}
\hline Treatment Symbol & Treatment Description \\
\hline $\mathrm{T}_{1}$ & control without any amendment (check) \\
\hline $\mathrm{T}_{2}$ & poultry manure (PM, equivalent to $100 \mathrm{~kg} \mathrm{~N} \mathrm{ha}^{-1}$ \\
\hline $\mathrm{T}_{3}$ & Wheat straw residues (WSR, equivalent to $\left.100 \mathrm{~kg} \mathrm{~N} \mathrm{ha}^{-1}\right)$ \\
\hline $\mathrm{T}_{4}$ & urea nitrogen (UN equivalent to $\left.100 \mathrm{~kg} \mathrm{~N} \mathrm{ha}^{-1}\right)$ \\
\hline $\mathrm{T}_{5}$ & $\mathrm{PM}+\mathrm{WSR}(50: 50)$ \\
\hline $\mathrm{T}_{6}$ & $\mathrm{UN}+\mathrm{PM}(50: 50)$ \\
\hline $\mathrm{T}_{7}$ & $\mathrm{UN}+\mathrm{WSR}(50: 50)$ \\
\hline $\mathrm{T}_{8}$ & $\mathrm{UN}+\mathrm{PM}+\mathrm{WSR}(50: 25: 25)$ \\
\hline
\end{tabular}

The treatments were assigned to the respective plots according to randomized complete block design (RCBD) with three replications. The net plot size was $3 \mathrm{~m} \times 2 \mathrm{~m}$ $\left(6 \mathrm{~m}^{2}\right.$ plot area). The time of sowing was selected on the basis of sowing time of a particular crop and availability of proper moisture in the field (depending upon the rainfall).

Well-rotten PM and dried WSR were broadcasted and well incorporated into the soil before the sowing of each crop for three consecutive cropping (wheat-soybean) cycles. In case of wheat, urea $\mathrm{N}$ was applied in two equal splits i.e. half dose at sowing and the remaining half at tillering while for soybean crop the urea $\mathrm{N}$ was splitted into three doses i.e. $50 \mathrm{~kg} \mathrm{~N}^{-1}$ at sowing and the remaining $50 \mathrm{~kg} \mathrm{~N}$ in further two equal splits (i.e. $25 \mathrm{~kg} \mathrm{~N} \mathrm{ha}^{-1}$ at flowering and $25 \mathrm{~kg} \mathrm{~N}^{-}$ ${ }^{1}$ at pod filling stages). In integrated $\mathrm{N}$ treatments, application of UN was also done in two or three splits accordingly. The same treatments were manually repeated for the 
subsequent years. The basal doses of phosphorus and potassium from single super phosphate (SSP) and sulfate of potash (SOP) were applied at the rate of $50 \mathrm{~kg} \mathrm{P}_{2} \mathrm{O}_{5}$ and $\mathrm{K}_{2} \mathrm{O}$ (each) to all plots including control at sowing of each crop in all the three years of experimentation. All the fertilizers were well mixed into the soil. Wheat (Triticum aestivum L) variety shafaq-2006 (at the rate of $120 \mathrm{~kg}$ seed $\mathrm{ha}^{-1}$ ) and soybean variety NARC-1 (at rate of 80 to $100 \mathrm{~kg}$ seed ha-1) were used as testing crops. All standard local cultural practices were followed when required throughout the growth period. No irrigation was provided, and manual weeding was carried out as per requirement (Table 3).

Table 3. Physio-chemical characteristics of Rawalakot soil and chemical composition of organic amendments used for field experimentation

\begin{tabular}{|c|c|c|c|c|c|c|c|c|}
\hline \multicolumn{5}{|c|}{ Soil } & \multicolumn{4}{|c|}{ Organic amendment } \\
\hline \multirow[b]{2}{*}{ Properties } & \multirow[b]{2}{*}{ Unit } & \multicolumn{3}{|c|}{ Depth (cm) } & \multirow[b]{2}{*}{ Properties } & \multirow[b]{2}{*}{ unit } & \multirow{2}{*}{$\begin{array}{c}\text { Poultry } \\
\text { manure } \\
\text { (PM) }\end{array}$} & \multirow{2}{*}{$\begin{array}{c}\text { Wheat straw } \\
\text { Residues } \\
\text { (WSR) }\end{array}$} \\
\hline & & $0-15$ & $16-30$ & Mean & & & & \\
\hline $\begin{array}{c}\text { Bulk } \\
\text { density }\end{array}$ & $\mathrm{g} \mathrm{cm}^{-3}$ & 1.36 & 1.48 & 1.42 & Total Nitrogen & $\mathrm{g} \mathrm{kg}^{-1}$ & 25.7 & 9.1 \\
\hline Sand & $\mathrm{g} \mathrm{kg}^{-1}$ & 434.0 & 427.0 & 426.0 & $\begin{array}{c}\text { Total } \\
\text { Phosphorus }\end{array}$ & $\mathrm{g} \mathrm{kg}^{-1}$ & 16.1 & 0.58 \\
\hline Silt & $\mathrm{g} \mathrm{kg}^{-1}$ & 326.0 & 343.0 & 304.0 & $\begin{array}{c}\text { Total } \\
\text { potassium }\end{array}$ & $\mathrm{g} \mathrm{kg}^{-1}$ & 18.1 & 11.4 \\
\hline Clay & $\mathrm{g} \mathrm{kg}^{-1}$ & 240.0 & 230.0 & 270.0 & Total Carbon & $\mathrm{g} \mathrm{kg}^{-1}$ & 349.2 & $418-0$ \\
\hline $\begin{array}{c}\text { Textural } \\
\text { class }\end{array}$ & ----- & \multicolumn{3}{|c|}{ Loam } & $\mathrm{C} / \mathrm{N}$ ratio & ---- & 13.6 & 45.9 \\
\hline $\begin{array}{c}\text { Soil pH } \\
\left(1: 2 \mathrm{H}_{2} \mathrm{O}\right)\end{array}$ & ----- & 6.89 & 7.01 & 6.95 & Calcium & $\mathrm{g} \mathrm{kg}^{-1}$ & 35.0 & 2.9 \\
\hline $\begin{array}{l}\text { Organic } \\
\text { matter }\end{array}$ & $\mathrm{g} \mathrm{kg}^{-1}$ & 10.3 & 8.92 & 7.90 & Magnesium & $\mathrm{g} \mathrm{kg}^{-1}$ & 6.20 & 1.7 \\
\hline Total N & $\mathrm{g} \mathrm{kg}^{-1}$ & 0.53 & 0.45 & 0.49 & Ash contents & $\mathrm{g} \mathrm{kg}^{-1}$ & 184.0 & $\begin{array}{ll}----- \\
\end{array}$ \\
\hline $\begin{array}{c}\text { Available } \\
\text { P }\end{array}$ & $\mathrm{mg} \mathrm{kg}^{-1}$ & 5.49 & 5.12 & 5.31 & Iron & $\mathrm{mg} \mathrm{kg}^{-1}$ & 1293.0 & 97.6 \\
\hline $\begin{array}{c}\text { Extractable } \\
\mathrm{K}\end{array}$ & $\mathrm{mg} \mathrm{kg}^{-1}$ & 98.5 & 87.8 & 93.2 & Zinc & $\mathrm{mg} \mathrm{kg}^{-1}$ & 428.2 & 17.4 \\
\hline Iron $(\mathrm{Fe})$ & $\mathrm{mg} \mathrm{kg}^{-1}$ & 17.8 & 7.36 & 12.6 & Manganese & $\mathrm{mg} \mathrm{kg}^{-1}$ & 641.5 & 65.8 \\
\hline $\begin{array}{l}\text { Manganese } \\
(\mathrm{Mn})\end{array}$ & $\mathrm{mg} \mathrm{kg}^{-1}$ & 6.2 & 4.0 & 5.1 & Copper & $\mathrm{mg} \mathrm{kg}^{-1}$ & 578.0 & 14.5 \\
\hline Zinc $(\mathrm{Zn})$ & $\mathrm{mg} \mathrm{kg}^{-1}$ & 8.4 & 3.9 & 6.15 & Cellulose & $\mathrm{g} \mathrm{kg}^{-1}$ & 67.9 & 429.0 \\
\hline $\begin{array}{l}\text { Copper } \\
(\mathrm{Cu})\end{array}$ & $\mathrm{mg} \mathrm{kg}^{-1}$ & 3.79 & 0.82 & 2.31 & Hemicellulose & $\mathrm{g} \mathrm{kg}^{-1}$ & ------ & 198.4 \\
\hline $\begin{array}{c}\text { Cation } \\
\text { exchange } \\
\text { capacity }\end{array}$ & $\begin{array}{l}\mathrm{cmol}_{(+)} \\
\mathrm{kg}^{-1} \text { soil }\end{array}$ & 11.9 & 10.6 & 11.3 & Lignin & $\mathrm{g} \mathrm{kg}^{-1}$ & 58.4 & 127.0 \\
\hline ------------- & ----- & ----- & ----- & ---- & Polyphenol & $\mathrm{g} \mathrm{kg}^{-1}$ & 208.7 & 43.1 \\
\hline
\end{tabular}

\section{Biochemical analysis of plant and grain samples}

Plant and grain samples of both wheat and soybean crops were dried in an air forced oven at $65^{\circ} \mathrm{C}$ for about 48 hours, ground in a Wiley mill (Polymix PX-MFC 90D;
Switzerland) to pass through a 1-mm sieve. Total $\mathrm{N}$ in ground plant material was estimated by Kjeldhal digestion, distillation and titration methods [13]. Total P and $\mathrm{K}$ were measured by digesting $0.25 \mathrm{~g}$ of material with sulfuric acid and hydrogen 
peroxide. The $\mathrm{P}$ in the digests was measured by colorimetry by using $\mathrm{P}$ standards of potassium dihydrogen phosphate [14] and $\mathrm{K}$ was determined by atomic absorption spectrophotometer [15]. Total N-P-K plant uptake was calculated from dry matter (DM) accumulation and NPK concentration in shoot of wheat and soybean.

Grain samples of wheat and soybean were also analyzed for $\mathrm{N}, \mathrm{P}$ and $\mathrm{K}$ concentrations using the procedures described for plant analysis and grain (wheat and soybean) N-P$\mathrm{K}$ uptake was calculated by multiplying grain $\mathrm{N}-\mathrm{P}-\mathrm{K}$ concentrations to their respective grain yields [16].

Nutrient input and output measurements and interpretations

The partial surface balancing of $\mathrm{N}, \mathrm{P}$ and $\mathrm{K}$ in wheat-soybean cropping system mainly based on four inputs i.e. mineral fertilizer, organic manures, crop residues and biological $\mathrm{N}_{2}$-fixation and sedimentations; and five outputs, i.e. nutrients removal in harvested grain products, removal by residues, leaching, gaseous losses and water erosion. Of these factors, we carried out the measurements of nutrients applications through mineral fertilizers, organic manures, crop residues recycling, biological $\mathrm{N}_{2-}$ fixation and rain water; and nutrients removal with harvested crop products and crop residues. The leaching, gaseous and water erosion losses of nutrients were not directly measured due to certain technical and practical constraints. However, the leaching losses of $\mathrm{N}$ and $\mathrm{K}$ were estimated with the help of following regression model [17].

$\mathrm{N}$ Leaching $=(0.0463+0.0037) \times(\mathrm{P} /(\mathrm{C} \times \mathrm{L})))$ $\times(\mathrm{F}+\mathrm{D} \times \mathrm{NOM}-\mathrm{U})$

$\mathrm{K}$ Leaching $=-6.87+0.0117 \times \mathrm{P}+0.173 \times \mathrm{F}-$ $0.265 \times \mathrm{CEC}$

Where

$\mathrm{P}=$ Annual precipitation $(\mathrm{mm}), \mathrm{C}=$ percentage of clay $(\%), \mathrm{L}=$ Layer thickness/rooting depth (m), F = Mineral and organic fertilizer nitrogen applied $\left(\mathrm{kg} \mathrm{N} \mathrm{ha}^{-1}\right)$
$\mathrm{D}=$ Annual decomposition rate $(1.6 \%$ year $\left.{ }^{1}\right), \mathrm{NOM}=$ Amount of $\mathrm{N}$ contained in soil organic matter $\left(\mathrm{kg} \mathrm{N} \mathrm{ha}^{-1}\right)$ and $\mathrm{CEC}=$ Cation exchange capacity ( $\mathrm{cmol}_{+} \mathrm{kg}^{-1}$ soil).

The gaseous $\mathrm{N}$ losses through denitrification and volatilization were estimated by using regression model developed by IFA and FAO [18]:

Gaseous $\mathrm{N}$ losses = $(0.025+0.000855 \times \mathrm{P}+0.01725 \times \mathrm{F}+0.117 \times \mathrm{O})$ $+0.113 \times \mathrm{F}$

Where

$\mathrm{P}=$ Annual precipitation $(\mathrm{mm}), \mathrm{F}=$ Mineral and organic fertilizer nitrogen applied $(\mathrm{kg} \mathrm{N}$ $\mathrm{ha}^{-1}$ ) and $\mathrm{O}=$ Organic carbon content (\%).

The surface partial nutrient balance for the system was calculated as:

$\mathrm{N} \mathrm{N}_{\mathrm{ab}}=\mathrm{N}_{\text {inp }}\left(\mathrm{N}_{\mathrm{f}}, \mathrm{N}_{\mathrm{m}}, \mathrm{W}_{\mathrm{r}}, \mathrm{N}_{\mathrm{r}}, \mathrm{N}_{\text {fix }}, \mathrm{N}_{\mathrm{c}}\right)-\mathrm{N}_{\text {outp }}$ $\left(\mathrm{N}_{\text {up }}, \mathrm{N}_{\mathrm{l}}, \mathrm{N}_{\mathrm{g}}\right)$

$P N_{a b}=N_{\text {inp }}\left(\mathrm{N}_{\mathrm{f}}, \mathrm{N}_{\mathrm{m}}, \mathrm{N}_{\mathrm{r}}, \mathrm{N}_{\mathrm{c}}\right)-\mathrm{N}_{\text {outp }}\left(\mathrm{N}_{\text {up }}\right)$

$K N_{a b}=N_{\text {inp }}\left(N_{\mathrm{f}}, N_{m}, N_{r}, N_{c}\right)-N_{\text {outp }}\left(N_{\text {up }}, N_{l}\right)$

Where $N_{a b}, P N_{a b}$ and $K N_{a b}$ are the surface $\mathrm{N}, \mathrm{P}$ and $\mathrm{K}$ balances, respectively; $\mathrm{N}_{\text {inp }}$ is the nutrient additions/inputs through mineral fertilizer $\left(\mathrm{N}_{\mathrm{f}}\right)$, poultry manure $\left(\mathrm{N}_{\mathrm{m}}\right)$, wheat straw $\left(\mathrm{W}_{\mathrm{S}}\right)$, rainwater $\left(\mathrm{N}_{\mathrm{r}}\right)$, atmospherically fixed nitrogen $\left(\mathrm{N}_{\mathrm{fix}}\right)$ and recycled crop residues $\left(\mathrm{N}_{\mathrm{c}}\right)$; $\mathrm{N}_{\text {outp }}$ is the nutrient removal/ output through uptake by grain and straw (for wheat) and grain and stalk (for soybean) $\left(\mathrm{N}_{\mathrm{up}}\right)$, leaching $\left(\mathrm{N}_{\mathrm{l}}\right)$ and gaseous losses $\left(\mathrm{N}_{\mathrm{g}}\right)$. The $\mathrm{N}, \mathrm{P}$ and $\mathrm{K}$ concentrations in rainwater were measured occasionally during 20092011 at the experimental site (Rawalakot). The measured data for all primary nutrients is variable in terms of inputs and outputs, therefore, the traditional analysis of variance (ANOVA) and least significant difference (LSD) test were not performed.

\section{Results and discussion}

Surface nitrogen balance

Averaged over a period of three years, the surface $\mathrm{N}$ balance showed a deficit of $\mathrm{N}$ ($41.2 \mathrm{~kg} \mathrm{ha}^{-1}$ year $^{-1}$ ) for the control soil. Application of different amendments and their combinations resulted in the positive $\mathrm{N}$ 
balance that varied between +40.7 to +86.8 $\mathrm{kg} \mathrm{ha}^{-1}$ year $^{-1}$ (Table 4). Maximum positive $\mathrm{N}$ balance was recorded for the $\mathrm{WSR}_{100}$ amended soil while the minimum was observed in case of $\mathrm{UN}_{100}$ treatment followed by $\mathrm{PM}_{50}+\mathrm{WSR}_{50}$. The maximum positive $\mathrm{N}$ balance in the WSR amended soil reflected the slower mineralization of the WSR and higher retention in the soil. The $\mathrm{N}$ leaching losses varied between 10.4 to $26.9 \mathrm{~kg} \mathrm{ha}^{-1}$ year $^{-1}$. The magnitude of $\mathrm{N}$ losses through leaching was maximum for the $\mathrm{WSR}_{100}$ followed by the treatment where both organic amendments were combined together i.e. $\mathrm{PM}_{50}+\mathrm{WSR}_{50}$. The higher $\mathrm{N}$ losses from WSR treated soil may be associated with late release of $\mathrm{N}$ from the WSR when crop demand for $\mathrm{N}$ diminishes. The $\mathrm{N}$ losses recorded in our study were higher than those of $22.2 \mathrm{~kg} \mathrm{~N}^{-1}$ year $^{-1}$ reported by [19] where they applied $\mathrm{N}$ at the rate of $200 \mathrm{~kg}^{-}$ ${ }^{1}$ to maize crop at the time of planting. The higher leaching losses in our case may be the result of higher total $\mathrm{N}$ applications $(600 \mathrm{~kg}$ $\mathrm{N} \mathrm{ha}^{-1}$ ) over three years and poor synchronization between $\mathrm{N}$ release and crop $\mathrm{N}$ uptake.

Among the organic amendments (PM, WSR and PM+WSR), the $\mathrm{N}$ balance ended up with $70.2,23.1$ and 28.0 percent increase over to the treatments where these amendments were combined with half UN. Similarly, among the combined treatments, the application of $\mathrm{UN}$ with WSR in $\mathrm{UN}_{50}+\mathrm{WSR}_{50}$ recorded higher leaching losses compared to the remaining two combined $\mathrm{N}$ treatments. The asynchronization between the $\mathrm{N}$ release from organic amendments and the crop $\mathrm{N}$ demand at later growth stages could promote the leaching of the $\mathrm{N}$ released from organic amendments.

The results of the present study indicated that the control soil showed negative $\mathrm{N}$ balance of $-41.2 \mathrm{~kg} \mathrm{ha}^{-1}$ year $^{-1}$ during three years of experimentation because no nitrogen input was added to the control soil. Our results are supported by the findings of [20] where they reported the negative nutrient balance $(-70 \mathrm{~kg}$ $\mathrm{N},-3 \mathrm{~kg} \mathrm{P}$ and $-21 \mathrm{~kg} \mathrm{~K} \mathrm{ha}^{-1}$ year $^{-1}$ ) for the un-amended soil. Among different amendments, the application of organic amendments particularly $\mathrm{WSR}_{100}$ recorded the highest positive $\mathrm{N}$ balance of $86.8 \mathrm{~kg} \mathrm{ha}^{-}$ ${ }^{1}$ year $^{-1}$, suggesting the slow and late release of $\mathrm{N}$ from WSR through mineralization and subsequently lower $\mathrm{N}$ uptake. The soil application of low quality crop residues limits nutrients availability to crops during early growth stages by extending the period of nutrients immobilization and results in poor synchronization and lower nutrient uptake [21]. Moreover, the soybean grown under organic treatments, exhibited higher $\mathrm{N}_{2}$ fixation due to improved soil physical conditions, added considerable amounts of crop residues and contributed to the positive soil $\mathrm{N}$ balance. The amount of $\mathrm{N}$ originally added to the soil system greatly depends on the amount of $\mathrm{N}$ translocated to the grains and on the amount of $\mathrm{N}$ recycled into the soil through crop residues [22]. The recycling of large amounts of crop residues into the soil from high $\mathrm{N}_{2}$ fixing soybeans and other legumes improves the $\mathrm{N}$ economy of cropping systems by adding additional $\mathrm{N}$ and positively affects soil $\mathrm{N}$ balance [23]. The soybean and other grain legumes meet 50-80 percent of their $\mathrm{N}$ requirements by fixing the atmospheric $\mathrm{N}$ and remove small amounts of soil mineral $\mathrm{N}$ than cereals thereby, positively contributing to $\mathrm{N}$ balance because of their 'sparing effects' and contribution through residue additions [24, 25]. The treatment receiving UN at the rate of $200 \mathrm{~kg}$ $\mathrm{N} \mathrm{ha}^{-1}$ year $^{-1}$ showed marginal build up of soil $\mathrm{N}$ (40.7 $\mathrm{kg} \mathrm{N} \mathrm{ha}^{-1} \mathrm{yr}^{-1}$ ) compared to all other treatments. The higher uptake of $\mathrm{N}$ from applied urea during early stages of growth and its leaching losses altogether might be the possible reason of lower positive $\mathrm{N}$ balance in UN amended soil. 
Table 4. Nitrogen balance of surface soil under wheat- soybean cropping following the application of poultry manure (PM), wheat straw residues (WSR), urea nitrogen (UN) and their combinations at Rawalakot, Azad Jammu and Kashmir (Average of 3 years: 2009, 2010 and 2011

\begin{tabular}{|c|c|c|c|c|c|c|c|c|c|c|c|c|c|c|}
\hline \multirow{3}{*}{ Treatment } & \multicolumn{8}{|c|}{ N-input (kg ha-1 year $\left.^{-1}\right)$} & \multicolumn{5}{|c|}{ N-output (kg ha-1 year $\left.^{-1}\right)$} & \multirow{3}{*}{$\begin{array}{c}\text { Surface } \\
\text { nitrogen } \\
\text { balance } \\
\left(\mathrm{kg} \mathrm{ha}^{-1} \text { year }^{-1}\right)\end{array}$} \\
\hline & \multirow[b]{2}{*}{$\begin{array}{c}\text { Fertilize } \\
\text { r }\end{array}$} & \multirow{2}{*}{$\begin{array}{c}\text { Poultry } \\
\text { manur } \\
\mathrm{e}\end{array}$} & \multirow{2}{*}{$\begin{array}{c}\text { Wheat } \\
\text { straw } \\
\text { residues (as } \\
\text { amendment } \\
\text { ) }\end{array}$} & \multirow{2}{*}{$\begin{array}{l}\text { Addition } \\
\text { by } \\
\text { soybean } \\
\text { residues }\end{array}$} & \multirow{2}{*}{$\begin{array}{l}\text { Addition } \\
\text { by wheat } \\
\text { residues }\end{array}$} & \multirow{2}{*}{$\begin{array}{l}\mathrm{N}_{2-} \\
\text { fixed by } \\
\text { soybean }\end{array}$} & \multirow[b]{2}{*}{$\begin{array}{c}\text { Rainfal } \\
1\end{array}$} & \multirow[b]{2}{*}{ Total } & \multicolumn{2}{|c|}{ Crop removal by } & \multirow[b]{2}{*}{$\begin{array}{c}\text { Leaching } \\
\text { losses }\end{array}$} & \multirow[b]{2}{*}{$\begin{array}{c}\text { Gaseous } \\
\text { losses }\end{array}$} & \multirow[b]{2}{*}{ Total } & \\
\hline & & & & & & & & & Wheat & Soybean & & & & \\
\hline Control & 0 & 0 & 0 & 21.2 & 10.0 & 57.6 & 0.55 & 89.4 & 34.6 & 94.7 & Nil & 1.3 & 130.5 & -41.2 \\
\hline $\mathrm{PM}_{100}$ & 0 & 200 & 0 & 28.7 & 14.4 & 71.5 & 0.55 & 315.1 & 61.8 & 134.1 & 20.9 & 27.3 & 244.1 & 70.9 \\
\hline $\mathrm{WSR}_{100}$ & 0 & 0 & 200 & 23.8 & 13.4 & 61.4 & 0.55 & 299.2 & 50.5 & 107.7 & 26.9 & 27.3 & 212.4 & 86.8 \\
\hline $\mathrm{UN}_{100}$ & 200 & 0 & 0 & 30.7 & 17.7 & 57.7 & 0.55 & 306.7 & 74.3 & 153.8 & 10.5 & 27.3 & 266.0 & 40.7 \\
\hline $\mathrm{PM}_{50}+\mathrm{WSR}_{50}$ & 0 & 100 & 100 & 25.0 & 13.1 & 63.0 & 0.55 & 301.7 & 55.2 & 113.7 & 24.9 & 27.3 & 221.1 & 80.6 \\
\hline $\mathrm{UN}_{50}+\mathrm{PM}_{50}$ & 100 & 100 & 0 & 33.8 & 16.5 & 58.8 & 0.55 & 309.7 & 79.8 & 150.5 & 10.4 & 27.3 & 268.0 & 41.7 \\
\hline $\mathrm{UN}_{50}+\mathrm{WSR}_{50}$ & 100 & 0 & 100 & 30.7 & 15.0 & 59.9 & 0.55 & 306.2 & 58.7 & 129.9 & 19.7 & 27.3 & 235.7 & 70.5 \\
\hline $\mathrm{UN}_{50}+\mathrm{PM}_{25}+\mathrm{WSR}_{25}$ & 100 & 50 & 50 & 31.3 & 15.4 & 65.7 & 0.55 & 312.9 & 65.9 & 139.4 & 17.3 & 27.3 & 249.9 & 63.0 \\
\hline
\end{tabular}

$\mathrm{UN}=$ urea nitrogen, $\mathrm{PM}=$ poultry manure and $\mathrm{WSR}=$ wheat straw residues 
In $\mathrm{UN}_{100}$ treatment, the $\mathrm{N}$ export in the wheat and soybean products (grain+ straw) represented 85.8 percent of the total output with the corresponding leaching loss of 10.5 $\mathrm{kg} \mathrm{N} \mathrm{ha}^{-1}$ year $^{-1}$ i.e. 2.2 to 5.3 percent of the total applied $\mathrm{N}$. The leaching losses calculated in our study are generally lower than that reported by [26] where they observed 9.0 percent translocation of applied $\mathrm{N}$ into the deeper soil layers in a field experiment on maize crop.

These results agreed with the findings of [27] who reported that plants can remove most of the $\mathrm{N}$ added through mineral fertilizers during the year of application, leaving little amount in soil for subsequent use or leaching. The higher leaching losses might be due to higher rainfall (> $1388 \mathrm{~mm}^{\text {year }}{ }^{-1}$ ), lack of synchronization between $\mathrm{N}$ release and crop demand and subsequently lower total $\mathrm{N}$ uptake by the crops. N-based applications of organic amendments in excess of crop demand increase the chances of $\mathrm{NO}^{-3}$ leaching.

Over three years, the combined $\mathrm{N}$ treatments recorded lower soil $\mathrm{N}$ balance $(41.7-70.5 \mathrm{~kg}$ $\mathrm{N} \mathrm{ha}^{-1} \mathrm{yr}^{-1}$ ) compared to the soil treated with organic amendments (70.9-86.8 $\mathrm{kg} \mathrm{N} \mathrm{ha}^{-1} \mathrm{yr}^{-}$ $\left.{ }^{1}\right)$. The average maximum annual soil $\mathrm{N}$ balance in our case for combined treatment (UN ${ }_{50}+\mathrm{WSR}_{50}$ ) was $70.5 \mathrm{~kg} \mathrm{~N} \mathrm{ha}^{-1} \mathrm{yr}^{-1}$ and strongly agreed with the findings of [28] who reported $87 \mathrm{~kg} \mathrm{ha}^{-1}$ annual additions of $\mathrm{N}$ to the soil of Nigeria following the combined application of organic and mineral fertilizers. The balanced supply of N, P, K and other essential nutrients from organic-inorganic amendments, improved growth and higher total nutrient uptakes may be responsible for decreased $\mathrm{N}$ balance in soil under combined treatments. [29] observed 8-12 percent decrease in soil $\mathrm{N}$ balance only due to the application of $200 \mathrm{~kg} \mathrm{~K} \mathrm{ha}{ }^{-1}$ because of increased $\mathrm{N}$ concentration and uptake in tomatoes.

\section{Surface phosphorus balance}

The $\mathrm{P}$ balance observed under different treatments (Table 5) indicated that the control soil recorded the minimum P-uptake of 16.4 $\mathrm{kg} \mathrm{ha}^{-1}$ year $^{-1}$ with a corresponding positive $\mathrm{P}$ balance of $83.7 \mathrm{~kg} \mathrm{ha}^{-1}$ year $^{-1}$ by the end of third year. Among different amendments, the $\mathrm{PM}_{100}$ alone recorded the maximum $\mathrm{P}$ gain of $196.3 \mathrm{~kg} \mathrm{ha}^{-1}$ year $^{-1}$ over three years followed by $\mathrm{PM}_{50}+\mathrm{WSR}_{50}$ i.e. $166.3 \mathrm{~kg} \mathrm{ha}^{-1}$ year ${ }^{-1}$, against the minimum $P$ balance of $66.7 \mathrm{~kg} \mathrm{ha}^{-}$ 1 yearr ${ }^{-1}$ in case of $\mathrm{UN}_{100}$. The highest $\mathrm{P}$ balance observed in $\mathrm{PM}_{100}$ treatment was probably due to the $\mathrm{P}$ contribution from PM, which additionally added $125 \mathrm{~kg} \mathrm{P}^{-1}$ year $^{-}$ ${ }^{1}$ (more than that from $\mathrm{P}$ fertilizer i.e. $100 \mathrm{~kg}$ $\mathrm{P}_{2} \mathrm{O}_{5} \mathrm{ha}^{-1}$ year $^{-1}$ ), a total of $376 \mathrm{~kg} \mathrm{P} \mathrm{ha}^{-1}$ in three years. In case of WSR 100 amended soil, the $\mathrm{P}$ balance was 57.3 percent higher compared to the control soil due to the contribution of $\mathrm{P}$ from WSR. When compared with combined $\mathrm{N}$ treatments, the organic amendments (PM, WSR and $\mathrm{PM}+\mathrm{WSR}$ ) increased the $\mathrm{P}$ balance by 47.2 , 27.3 and 36.0 percent, respectively. For the combined $\mathrm{N}$ treatments, the application of $\mathrm{UN}_{50}+\mathrm{PM}_{50}$ recorded 9.0-22.7 percent higher $\mathrm{P}$ accumulations, compared to the remaining two treatments i.e. $\mathrm{UN}_{50}+\mathrm{WSR}_{50}$ and $\mathrm{UN}_{50}+\mathrm{PM}_{25}+\mathrm{WSR}_{25}$.

The results indicated that all treatments (including control) exhibited positive $\mathrm{P}$ balance for the three years. The magnitude of $\mathrm{P}$ build up was higher for the organic amendments compared to the combined $\mathrm{N}$ treatments and maximum $\mathrm{P}$ accumulation was observed for the soil amended with $\mathrm{PM}_{100}$. The sum basal applications of $300 \mathrm{~kg}$ $\mathrm{P}_{2} \mathrm{O}_{5}$ through SSP fertilizer plus extra addition of $376 \mathrm{~kg} \mathrm{P} \mathrm{ha}^{-1}$ from PM (altogether $676 \mathrm{~kg} \mathrm{P}$ ) and lower total P uptake (91 and 87 $\mathrm{kg}$ total P-uptake (i.e. 13 and 12 percent of the total P-input) was probably responsible for higher $\mathrm{P}$ accumulations in PM amended soil. 
Table 5. Phosphorus balance of surface soil under wheat- soybean cropping following the application of poultry manure (PM), wheat straw residues (WSR), urea nitrogen (UN) and their combinations at Rawalakot, Azad Jammu and Kashmir (Average of 3 years: 2009, 2010 and 2011

\begin{tabular}{|c|c|c|c|c|c|c|c|c|c|c|c|}
\hline \multirow{3}{*}{ Treatments } & \multicolumn{2}{|c|}{$\begin{array}{c}\text { Crop yields (kgha } \\
\text { 1 }^{-} \text {year }^{-1} \text { ) }\end{array}$} & \multicolumn{5}{|c|}{ P-input (kg ha-1 year $\left.^{-1}\right)$} & \multicolumn{3}{|c|}{ P-output (kg ha-1 year $^{-1}$ ) } & \multirow{3}{*}{$\begin{array}{c}\text { Surface phosphorus } \\
\text { balance } \\
\left(\mathrm{kg} \mathrm{ha}^{-1} \text { year }^{-1}\right)\end{array}$} \\
\hline & \multirow{2}{*}{ Wheat } & \multirow[b]{2}{*}{ soybean } & \multirow[b]{2}{*}{ Fertilizer } & \multirow{2}{*}{$\begin{array}{l}\text { Poultry } \\
\text { manure }\end{array}$} & \multirow{2}{*}{$\begin{array}{c}\text { Wheat straw } \\
\text { residues }\end{array}$} & \multirow[b]{2}{*}{ Rainfall } & \multirow{2}{*}{ Total } & \multicolumn{2}{|c|}{ Crop removal } & \multirow{2}{*}{ Total } & \\
\hline & & & & & & & & Wheat & soybean & & \\
\hline Control & 1203 & 1024 & 100 & 0 & 0 & 0.17 & 100.3 & 6.7 & 9.7 & 16.4 & 83.7 \\
\hline $\mathrm{PM}_{100}$ & 1855 & 1246 & 100 & 125 & 0 & 0.17 & 225.7 & 15.0 & 14.1 & 29.1 & 196.3 \\
\hline $\mathrm{WSR}_{100}$ & 1593 & 1080 & 100 & 0 & 60 & 0.17 & 160.3 & 9.5 & 14.0 & 23.5 & 136.7 \\
\hline $\mathrm{UN}_{100}$ & 2142 & 1463 & 100 & 0 & 0 & 0.17 & 100.3 & 14.8 & 18.5 & 33.4 & 66.7 \\
\hline $\mathrm{PM}_{50}+\mathrm{WSR}_{50}$ & 1726 & 1121 & 100 & 63 & 30 & 0.17 & 193.0 & 11.3 & 15.0 & 26.4 & 166.3 \\
\hline $\mathrm{UN}_{50}+\mathrm{PM}_{50}$ & 2164 & 1327 & 100 & 63 & 0 & 0.17 & 163.0 & 17.4 & 19.1 & 36.4 & 126.3 \\
\hline $\mathrm{UN}_{50}+\mathrm{WSR}_{50}$ & 1821 & 1266 & 100 & 0 & 30 & 0.17 & 130.3 & 13.6 & 14.5 & 28.0 & 102.0 \\
\hline $\mathrm{UN}_{50}+\mathrm{PM}_{25}+\mathrm{WSR}_{25}$ & 1896 & 1300 & 100 & 31 & 15 & 0.17 & 146.7 & 14.6 & 15.8 & 30.4 & 116.0 \\
\hline
\end{tabular}

$\mathrm{UN}=$ urea nitrogen, $\mathrm{PM}=$ poultry manure and $\mathrm{WSR}=$ wheat straw residues 
The higher $\mathrm{P}$ levels in organically amended soil may also be associated with slower mineralization of added organic P. These results are supported by [30] who explained that major portion of $\mathrm{P}$ added to soil through organic amendments exists in organic fractions that get mineralized slowly over time. There was a three-fold increase in soil $\mathrm{P}$ level as compared to the values that were obtained before the start of experiment due to continuous application of poultry litter [10, 31 .

Moreover, [30] reported that 73 percent higher $\mathrm{P}$ accumulations in soil following the repeated application of PM for three consecutive years in a rice-wheat cropping sequence compared to the NPK fertilizer alone. Similarly, [32] reported higher residual $\mathrm{P}$ accumulations under organic inputs than mineral counterparts. Moreover, the application of $\mathrm{PM}$ at rates to meet $\mathrm{N}$ requirements of crops results in excessive $P$ accumulation in the amended soil. Some other researchers [31, 33] had reported the eutrophication of ground water due to the leaching and runoff losses of excessively accumulated soil $P$. The minimum $P$ balance in $\mathrm{UN}_{100}$ treatment may be the result of higher total $\mathrm{P}$ uptake and small extra $\mathrm{P}$ additions (47 to $53 \mathrm{~kg} \mathrm{P} \mathrm{ha}^{-1}$ over three years) through the recycled wheat-soybean crop residues. Among the combined treatments, the $\mathrm{P}$ balance of the $\mathrm{UN}_{50}+\mathrm{PM}_{50}$ treatment was 22.8 and 9.0 percent higher compared with other two combined treatments i.e. $\mathrm{UN}_{50}+\mathrm{WSR}_{50}$ and $\mathrm{UN}_{50}+\mathrm{PM}_{25}+\mathrm{WSR}_{25}$, respectively. The comparatively low $\mathrm{P}$ additions in soil under combined treatments was probably due to higher total $\mathrm{P}$ uptake by both crops and small contribution of applied organic amendments. [28] Reported upto 33 $\mathrm{kg}$ annual $\mathrm{P}$ additions in soils due to combined application of organic manures and mineral $\mathrm{N}$ fertilizers. The reason for higher $\mathrm{P}$ values in our experiment is that we have summarized the $\mathrm{P}$ additions of all the three years of study instead of average annual values. The magnitude of soil $\mathrm{P}$ accumulation for all the treatments receiving the combination of PM followed the decreasing order: $\mathrm{PM}_{100}>\mathrm{PM}_{50}+\mathrm{WSR}_{50}>\mathrm{UN}_{50}+\mathrm{PM}_{50}>$ $\mathrm{UN}_{50}+\mathrm{PM}_{25}+\mathrm{WSR}_{25}$.

\section{Surface potassium balance}

Averaged over a period of three years, the K balance in the control soil under the wheatsoybean cropping systems remained slightly positive (16.5 kg K ha-1 $\mathrm{year}^{-1}$ ). A total basal application of $300 \mathrm{~kg} \mathrm{~K}_{2} \mathrm{O} \mathrm{ha}^{-1}$ from sulphate of potash (SOP) over three years is responsible to increase and maintain the positive $\mathrm{K}$ balances in the control soil. In most of the cases, the application of organic amendments and their combinations with half $\mathrm{UN}$ recorded positive $\mathrm{K}$ balances over three years that varied between +1.3 to $16.5 \mathrm{~kg} \mathrm{ha}^{-}$ 1 . However, the application of UN alone and with $\mathrm{PM}$ in $\mathrm{UN}_{100}$ and $\mathrm{UN}_{50}+\mathrm{PM}_{50}$ treatments showed negative $\mathrm{K}$ balances of -12.3 and $17.1 \mathrm{~kg} \mathrm{~K} \mathrm{ha}^{-1}$ year $^{-1}$, respectively (Table 6). The negative $\mathrm{K}$ balances in these two treatments could be associated with higher Kuptake by the crops ( 83.0 percent of the total $\mathrm{K}$ output), indicating the need for more $\mathrm{K}$ addition to sustain crop yield. Among all the amendments, the application of $\mathrm{WSR}_{100}$ at both the sites recorded the maximum positive $\mathrm{K}$ balances followed by $\mathrm{PM}_{50}+\mathrm{WSR}_{50}$.

Averaged over the three years, the K leaching losses among the amendments varied between 26.7 to $34.2 \mathrm{~kg}$ ha $^{-1}$ year $^{-1}$, representing the relative increase of 10.0 to 40.9 percent, respectively, over to the control. In spite of high total rain fall, the lower $\mathrm{K}$ losses through leaching might be associated with fine soil texture (higher clay contents) and slower release of $\mathrm{K}$ from the added amendments during winter.

Results of our study revealed that the control soil recorded the positive $\mathrm{K}$ balance of 16.5 $\mathrm{kg} \mathrm{ha}^{-1}$ year $^{-1}$ with the corresponding leaching loss of $24.3 \mathrm{~kg} \mathrm{~K} \mathrm{ha}^{-1}$ year $^{-1}$. The positive K balance in the control soil may be due to the 
annual additions of $100 \mathrm{~kg} \mathrm{~K}_{2} \mathrm{O} \mathrm{ha} \mathrm{ha}^{-1}$ from sulphate of potash (SOP) over a period of three years. The $\mathrm{K}$ losses recorded in our study for the control treatment were approximately five times higher than the $\mathrm{K}$ loss of $15 \mathrm{~kg} \mathrm{ha}^{-1}$ reported by [34] from the control soil after three years of soybeanwheat cropping. The K application from both SOP and organic amendments beyond crop requirement and higher monsoon rainfall are the possible causes of higher losses in our study. Among different amendments, the application of UN alone or with PM (i.e. $\mathrm{UN}_{100}$ and $\mathrm{UN}_{50}+\mathrm{PM}_{50}$ ) recorded the negative $\mathrm{K}$ balance of -12.3 and $-17.1 \mathrm{~kg} \mathrm{ha}$ ${ }^{1}$ year $^{-1}$, respectively. This negative $\mathrm{K}$ balance may be associated with the removal of $\mathrm{K}$ in large amounts through plant uptake and leaching and low K contents of applied PM. The values of negative $K$ balance recorded in our study are comparable with those reported by [35] where the values of negative $K$ balance varies from -6.9 (in $\mathrm{NK}$ amended plots) to $-82.2 \mathrm{~kg} \mathrm{ha}^{-1} \mathrm{yr}^{-1}$ (for $\mathrm{N}+\mathrm{FYM}$ treated plots). Similarly, [36] also reported negative soil $\mathrm{K}$ balance for the treatment receiving combined application of $\mathrm{PM}+$ mineral $\mathrm{N}$ fertilizer over four consecutive years. In addition, [37] also reported negative $\mathrm{K}$ balances of -52.2 to $181.5 \mathrm{~kg} \mathrm{ha}^{-1} \mathrm{yr}^{-1}$ in their long-term (28 years) experiments for integrated nutrient management in rice-wheat cropping systems at Bihar, India.

The maximum increase in $\mathrm{K}$ balance (37-64 percent over control) was recorded for the treatment receiving $\mathrm{WSR}_{100}$ at both the sites. Despite of substantial leaching losses of $\mathrm{K}$ from WSR amended soil (21.6 to 22.1 percent of the total $\mathrm{K}$ output), the higher $\mathrm{K}$ build up was attributable to the highest total $\mathrm{K}$ input of 556.3 to $573.9 \mathrm{~kg} \mathrm{ha}^{-1}$ from the recycled residues $+\mathrm{K}$ fertilizer and lowest $\mathrm{K}$ uptake by the crops among all treatments. The increased leaching losses of $\mathrm{K}$ from WSR amended soil reflect higher $\mathrm{K}$ release from the added WSR. [38] explained that the $\mathrm{K}$ in mature plant residues exists in ionic form and soil incorporation of such type of residues quickly release $\mathrm{K}$ into the soil solution from where it is either taken up by the growing plants or lost through leaching. The contribution of $12 \mathrm{~kg} \mathrm{ha}^{-1}$ extra K addition through WSR during three years, slower mineralization rates, lack of synchrony between $\mathrm{K}$ release and uptake by crop and consequently lower total $\mathrm{K}$ uptake by the crop are mainly responsible for the increased accumulation of $\mathrm{K}$ in WSR amended soil.

Among the combined $\mathrm{N}$ treatments, the $\mathrm{K}$ balance for the $\mathrm{UN}_{50}+\mathrm{WSR}_{50}$ and $\mathrm{UN}_{50}+\mathrm{PM}_{25}+\mathrm{WSR}_{25}$ was substantially lower compared to the control and varied between 1.3-5.2 $\mathrm{kg} \mathrm{ha}^{-1} \mathrm{year}^{-1}$. The higher $\mathrm{K}$ uptake by plants and increased leaching losses of applied $\mathrm{K}$ from these two combined treatments may be the possible cause of this difference. When expressed on annual basis, the $\mathrm{K}$ leaching losses recorded in our experiment under different amendments (26.7-34.2 $\mathrm{kg} \mathrm{ha}^{-1} \mathrm{year}^{-1}$ ) are much closer to the values $\left(32.0 \mathrm{~kg} \mathrm{~K} \mathrm{ha}^{-1} \mathrm{year}^{-1}\right.$ ) reported by [39] for a NPK+FYM amended soil under a long-term (30 years) experiment. 
Table 6. Potassium balance of surface soil under wheat- soybean cropping following the application of poultry manure (PM), wheat straw residues (WSR), urea nitrogen (UN) and their combinations at Rawalakot, Azad Jammu and Kashmir (Average of 3 years: 2009, 2010 and 2011

\begin{tabular}{|c|c|c|c|c|c|c|c|c|c|c|c|c|c|c|}
\hline \multirow{3}{*}{ Treatment } & \multicolumn{2}{|c|}{$\begin{array}{c}\text { Crop yields (kgha } \\
\left.1_{\text {year }^{-1}}\right)\end{array}$} & \multicolumn{7}{|c|}{ K-input (kg ha ${ }^{-1}$ year $\left.^{-1}\right)$} & \multicolumn{4}{|c|}{ K-output (kg ha-1 year $^{-1}$ ) } & \multirow{3}{*}{$\begin{array}{c}\text { Surface } \\
\text { potassium } \\
\text { balance } \\
\left(\text { kgha }^{1} \text { year }^{-1}\right)\end{array}$} \\
\hline & \multirow[b]{2}{*}{ Wheat } & \multirow[b]{2}{*}{ Soybean } & \multirow[b]{2}{*}{$\begin{array}{c}\text { Fertilize } \\
\mathbf{r}\end{array}$} & \multirow{2}{*}{$\begin{array}{c}\text { Poultr } \\
\text { y } \\
\text { manur } \\
\text { e }\end{array}$} & \multirow{2}{*}{$\begin{array}{c}\text { Wheat } \\
\text { straw } \\
\text { residues }\end{array}$} & \multirow{2}{*}{$\begin{array}{c}\text { Addition by } \\
\text { soybean } \\
\text { residues }\end{array}$} & \multirow{2}{*}{$\begin{array}{c}\text { Addition } \\
\text { by wheat } \\
\text { residues }\end{array}$} & \multirow[b]{2}{*}{ Rainfall } & \multirow[b]{2}{*}{ Total } & \multicolumn{2}{|c|}{ Crop removal by } & \multirow[b]{2}{*}{$\begin{array}{c}\text { Leachin } \\
\text { g losses }\end{array}$} & \multirow[b]{2}{*}{ Total } & \\
\hline & & & & & & & & & & Wheat & Soybean & & & \\
\hline Control & 1203 & 1024 & 100 & 0 & 0 & 12.0 & 15.7 & 0.4 & 128.1 & 39.1 & 48.2 & 24.3 & 111.6 & 16.5 \\
\hline $\mathrm{PM}_{100}$ & 1855 & 1246 & 100 & 23 & 0 & 15.2 & 20.5 & 0.4 & 159.5 & 55.8 & 61.1 & 31.8 & 148.7 & 10.8 \\
\hline $\mathrm{WSR}_{100}$ & 1593 & 1080 & 100 & 0 & 42 & 15.3 & 27.5 & 0.4 & 185.4 & 62.9 & 61.0 & 34.2 & 158.1 & 27.3 \\
\hline $\mathrm{UN}_{100}$ & 2142 & 1463 & 100 & 0 & 0 & 18.1 & 23.6 & 0.4 & 142.0 & 54.3 & 73.4 & 26.7 & 154.4 & -12.3 \\
\hline $\mathrm{PM}_{50}+\mathrm{WSR}_{50}$ & 1726 & 1121 & 100 & 12 & 21 & 14.7 & 20.9 & 0.4 & 168.8 & 59.1 & 61.9 & 31.3 & 152.3 & 16.5 \\
\hline $\mathrm{UN}_{50}+\mathrm{PM}_{50}$ & 2164 & 1327 & 100 & 12 & 0 & 17.1 & 22.8 & 0.4 & 152.0 & 69.6 & 71.1 & 28.4 & 169.1 & -17.1 \\
\hline $\mathrm{UN}_{50}+\mathrm{WSR}_{50}$ & 1821 & 1266 & 100 & 0 & 21 & 17.2 & 26.2 & 0.4 & 164.9 & 65.1 & 63.9 & 30.7 & 159.7 & 5.2 \\
\hline $\begin{array}{c}\mathrm{UN}_{50}+\mathrm{PM}_{25}+ \\
\mathrm{WSR}_{25}\end{array}$ & 1896 & 1300 & 100 & 6 & 11 & 16.6 & 22.7 & 0.4 & 156.1 & 60.4 & 65.2 & 29.1 & 154.8 & 1.3 \\
\hline
\end{tabular}

$\mathrm{UN}=$ urea nitrogen, $\mathrm{PM}=$ poultry manure and $\mathrm{WSR}=$ wheat straw residues 


\section{Conclusion}

These 3-year field experiments on wheatsoybean cropping under integrated nutrient management have provided a framework that organic amendments particularly wheat straw residues, alone and along with urea $\mathrm{N}$, have the potential to improve NPK balance of surface soil. Whereas, the soil amended with $\mathrm{UN}, \mathrm{PM}$ or $\mathrm{UN}+\mathrm{PM}$ combinations displayed marginal increases in $\mathrm{N}$ and $\mathrm{P}$ balance. Although, the organic amendments alone showed little improvements in crop yield during three years but their positive contribution towards improving overall soil quality and nutrient status of degraded soils cannot be ignored. Therefore, these results suggested the application of organic amendments (of plant and animal origin) with mineral $\mathrm{N}$ fertilizer for improving both wheat-soybean productivity and nutrient levels of degraded soils under the hilly agroecosystem of Himalayan region of Azad Jammu and Kashmir. The study further revealed that the $\mathrm{K}$ fertilization practiced in our experiments at the rate of $50 \mathrm{~kg} \mathrm{~K}_{2} \mathrm{O} \mathrm{ha}^{-1}$ year $^{-1}$ is insufficient and need to be increased to rectify the $\mathrm{K}$ imbalance and sustain crop yields in the region. These findings highlight that the combined application of WSR and mineral fertilizers can help to buildup $\mathrm{N}$ and $P$ stocks in surface soil.

\section{Authors' contributions}

Conceived and designed the experiments: Khaliq A \& Abbasi MK, Performed the experiments: Khaliq A, Analyzed the data: Zafar M \& Sarwar S, Contributed materials/ analysis/tools: Khaliq A, Zafar M \& Tahir MM, Wrote the paper: Khaliq A \& Zafar M.

\section{References}

1. Tiwari KR, Sitaula BK, Bajracharya RM \& Børresen T (2010). Effects of soil and crop management practices on yields, income and nutrients losses from upland farming systems in the middle mountains region of Nepal. Nutr Cycl Agroecosys 86: 241-253.
2. Goodlass G, Halberg N \& Verschuur G (2003). Input output accounting systems in the European community - an appraisal of their usefulness in raising awareness of environmental problems. Eur J Agron 20: 17-24.

3. Neugschwandtner RW, Liebhard P, Kaul HP \& Wagentrist H (2014). Soil chemical properties as affected by tillage and crop rotation in a long-term field experiment. Plant Soil Environ 60: 57-62.

4. Subbarao GV, Ito O, Sahrawat KL, Berry WL, Nakahara KT, Ishikawa, Watanabe T, Suenaga K, Rondon M \& Rao IM (2006). Scope and strategies for regulation of nitrification in agricultural systemschallenges and opportunities. Crit Rev Plant Sci 25: 303-335.

5. Tiwari KR, Nyborg ILP, Sitaula BK \& Paudel GS (2008). Analysis of the sustainability of upland farming systems in the middle mountains region of Nepal. Int J Agr Sustain 6: 289-306.

6. Ribeiro HM, Fangueiro D, Alves F, Ventura R, Coelho D, Vasconcelos E, Cunha-Queda C, Coutinho J \& Cabral F (2010). Nitrogen mineralization from an organically managed soil and nitrogen accumulation in lettuce. $J$ Plant Nutr Soil Sc 173: 260-267.

7. Nikoli $T \&$ Matsi $T$ (2011). Influence of liquid cattle manure on micronutrients content and uptake by corn and their availability in a calcareous soil. Agron $J$ 103: 113-118.

8. Rao SS (2003). Nutrient balance and economics of integrated nutrient management in groundnut (Arachis hypogaea L.) - mustard (Brassica juncea L.). Madras Agric J 90: 465-471.

9. Abbasi MK \& Tahir MM (2012). Economizing nitrogen fertilizer in wheat through combinations with organic manures in Kashmir, Pakistan. Agron J 104: 169-177.

10. Palm CA, Myers RJK \& Nandwa SM (1997). Combined use of organic and inorganic nutrient sources for soil fertility management and replenishment. In: 
Buresh RJ, Sanchez PA \& Calhoun F (eds.) Replenishing soil fertility in Africa.

11. Khaliq A \& Abbasi MK (2015). Improvements in the physical and chemical characteristics of degraded soils supplemented with organic-inorganic amendments in the Himalayan region of Kashmir, Pakistan. Catena 126: 209-219.

12. Zafar M, Abbasi MK \& Khaliq A (2013). Effect of different phosphorus sources on the growth, yield, energy content and phosphorus utilization efficiency in maize at Rawalakot Azad Jammu and Kashmir. J Plant Nutr 36: 1915-1934.

13. Bremner JM \& Mulvaney CS (1982). Nitrogen-total. In: Page A L, Miller R H, Keeney D R. (eds.) Methods of soil analysis, part 2. Chemical and microbiological properties. SSSA Madison W.I.P. 595-624.

14. Murphy J \& Riley JP (1962). A modified single solution for determination of phosphate in natural waters. Anal Chim Acta 27: 31-36.

15. Winkleman GE, Amin KK, Rice WA \& Tahir MB (1990). Methods Manual Soil Laboratory. BARD Project, PARC, Islamabad, Pakistan.

16. Fernandez FG, Brouder SM, Beyrouty CA, Jeffrey, Volene J \& Hoyum R (2008). Assessment of plant available Potassium for no-till rainfed soybean. Soil Sci Soc Am J 72: 1085-1095.

17. De Willigen $P$ (2000). An analysis of the calculation of leaching and denitrification losses as practiced in the NUTMON approach. Report 18. Wageningen, The Netherlands: Plant Research International.

18. Lesschen J, Asiamah RD, Gicheru P, Kante S, Stoorvogel JJ \& Smaling EMA (2003). Scaling soil nutrient balances. FAO-WU-SRIG-KARI-IER. Rome: FAO.

19. Costa JL, Bedmar F, Daniel PE \& Aparicio VC (2003). Nitrate and atrazine leaching from corn in the Argentinean Humid Pampas. p. 241-245. In Halm D, Grathwohl P. (ed.) Proc. Int. Workshop on groundwater risk assessment at contaminated sites and integrated soil and water protection, 2nd, Tubingen, Germany. 20-21 March 2003. Eberhard Karls Universita t Tubingen Publ., Tubingen, Germany.

20. Kanmegne J, Smaling EMA, Brussaard L, Gansop-Kouomegne A \& Boukong A (2006). Nutrient flows in smallholder production systems in the humid forest zone of southern Cameroon. Nutr $\mathrm{Cycl}$ Agroecosys 76: 233-248.

21. Vanlauwe B, Gachengo C, Shepherd C, Barrios E, Cadisch G \& Palm CA (2005). Laboratory validation of a resource quality-based conceptual framework for organic matter management. Soil Sci Soc Am J 69: 1135-1145.

22. Giller KE \& Cadisch G (1997). Driven by Nature: Asense of arrival or departure? In Driven by Nature. Plant litter quality and decomposition, ed. Cadisch G, Giller K E, $\mathrm{CAB}$ international, Wallingford, UK. pp. 393-399.

23. Shah Z, Shah SH, Peoples MB, Schwenke GD\& Herriedge DF (2003). Crop residue and fertilizer $\mathrm{N}$ effects on nitrogen fixation and yields of legume- cereal rotations and soil organic fertility. Field Crops Res 83: 1-11.

24. Salvagotti FKG, Cassman JE, Specht DT, Walters A \& Dobermann A (2008). Nitrogen uptake, fixation and response to fertilizer in soybean: A review. Field Crops Res 10: 1-11.

25. Sainju UM, Lenssen AW, Allen BL \& Stevens WB (2016). Nitrogen balance in response to dryland rotations and cultural practices. Agr Ecosyst Environ 233: 25-32.

26. Kimetu JM, Mugendi DN, Bationo A, Palm CA, Mutuo PK, Kihara J \& Giller K (2006). Partial balance of nitrogen in a maize cropping system in humic nitisol of Central Kenya. Nutr Cycl Agroecosys 76: 261-270.

27. Gutser R, Ebertseder TH, Weber A, Schraml M \& Schmidhalter U (2005). Short-term and residual availability of nitrogen after long-term application of organic fertilizers on arable land. $J$ Plant Nutr Soil Sc 168: 439-446. 
28. Hoffmann I, Gerling D, Kyiogwom UB \& Mane-Bielfeldt A (2001). Farmers' management strategies to maintain soil fertility in a remote area in northwest Nigeria. Agr Ecosyst Environ 86: 263275.

29. Liu E, Yan C, Mei X, He W, Bing SH, Ding L, Liu Q, Liu S \& Fan T (2010). Long-term effect of chemical fertilizer, straw, and manure on soil chemical and biological properties in northwest China. Geoderma 158: 173-180.

30. Yadvinder S, Gupta RK, Thind HS, Bijay S, Singh V, Singh G, Singh J \& Ladha JK (2009). Poultry litter as a nitrogen and phosphorous source for the rice-wheat cropping system. Biol Fert Soils 45: 701710.

31. Zafar M, Rizwan MS \& Shahid M (2017a). Introduction of composted rock phosphate and poultry manure enhances winter wheat phosphorus use efficiency, grain yield and soil quality. J Plant Nutr 44: 1887-1899.

32. Frederik VDB, Magid J \& Jensen LS (2017). Long-term P and K fertilization strategies and balances affect soil availability indices, crop yield depression risk and N use. Eur J Agron 86: 12-23.

33. Zafar M, Tiecher T, Capoane V, Troian A \& Santos DR (2017). Characteristics, lability and distribution of phosphorus in suspended sediment from a subtropical catchment under diverse anthropic pressure in Southern Brazil. Ecol Eng 100: $28-45$.

34. Ramesh P, Panwar NR, Singh AB, Ramana S \& Rao AS (2009). Impact of organic-manure combinations on the productivity and soil quality in different cropping systems in central India. J Plant Nutr Soil Sc 172: 577-585.

35. Prakash YS, Bhadoria PBS \& Rakshit A (2007). Comparative efficacy of organic manures on the changes in soil properties and nutrient availability in an Alfisols. $J$ India Soc Soil Sc 50: 219-221.

36. Amusan AO, Adetunji MT, Azeez JO \& Bodunde JG (2011). Effect of the integrated use of legume residue, poultry manure and inorganic fertilizers on maize yield, nutrient uptake and soil properties. Nutr Cycl Agroecosys 90: 321-330.

37. Das A, Sharma RP, Chattopadhyaya N \& Rakshit R (2014). Yield trends and nutrient budgeting under a long-term (28 years) nutrient management in rice-wheat cropping system under subtropical climatic condition. Plant Soil Environ 60: 351-357.

38. Lupwayi NZ, Clayton GW, Donovan JTO, Harker KN, Turkington TK \& Soon YK (2006). Potassium release during decomposition of crop residues under conventional and zero tillage. Can J Soil Sci 86: 473-481.

39. Kundu S, Bhattacharyya R, Prakash V, Ghosh BN, Pathak H, Gupta HS and Ladha JK. (2007). Long-term yield trend and sustainability of rainfed soybean-wheat system through farmyard manure application in a sandy loam soil of the Indian Himalayas. Biol Fert Soils 43: 271280. 